International Research Journal of Management, IT \& Social Sciences
Available online at https://sloap.org/journals/index.php/irjmis/
Vol. 9 No. 1, January 2022, pages: 1-9
ISSN: 2395-7492
https://doi.org/10.21744/irjmis.v9n1.1994

\title{
Identification of the Effectiveness of Higher Education Marketing Strategies Using Social Media
}

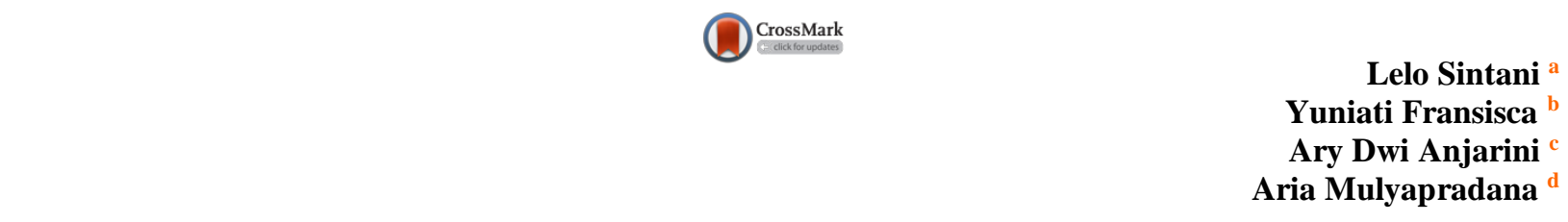

Article history:

Submitted: 09 September 2021

Revised: 18 October 2021

Accepted: 27 November 2021

\section{Keywords:}

effectiveness;

higher education;

marketing;

review data;

social media;

\begin{abstract}
There are many ways that universities can promote their programs and services to get the attention of prospective buyers. One strategy is to use social media to promote its products and services. Furthermore, the author believes that the successful promotion of various products owned by investment will determine the University's progress. We obtained data from publications such as comma books, journals, and several websites discussing university marketing promotion issues on social media pages to fill out this discussion. To answer this royal question, we have to go through the data analysis process by following the rules of scientific studies, including through a coding data evaluation system and drawing conclusions considering that the data we present is valid and reliable. Finally, we can conclude after reviewing the data and also in-depth discussions where we found that the effectiveness of marketing through social media for investment products and services is very appropriate and effective considering that today social media has become a place not only for young people to be friends but also a place for young people to become friends, and literature for business purposes as well as promotion including promotion of high change programs.
\end{abstract}

International research journal of management, IT and social sciences (C) 2022. This is an open access article under the CC BY-NC-ND license (https://creativecommons.org/licenses/by-nc-nd/4.0/).

Corresponding author:

Lelo Sintani,

Universitas Palangka Raya, Indonesia.

Email address: Lelo.Sintani@feb.upr.ac.id

${ }^{a}$ Universitas Palangka Raya, Indonesia

${ }^{\mathrm{b}}$ Universitas Nurtanio Bandung, Indonesia

Politeknik Pusmanu, Pekalongan, Indonesia

${ }^{d}$ Politeknik Pusmanu, Pekalongan, Indonesia 


\section{Introduction}

Lately, the existence of social media is not only a place for friendship and games lovers, but they have also become a center of attention for many people such as business owners, technocrats, arts and culture performers, government, and even higher education institutions to promote their university business products (Tulu, 2017; Putra et al., 2020; Sudarmo et al., 2021). Therefore, the existence of social media becomes a significant part of higher education management circles in promoting academic activities, including program marketing channels and promoting the success of their students' work. The reason is that social media can reach all levels of society, especially the younger generation who need instant information about university activities and business sharing sessions (Biczysko \& Jablońska, 2016; Dewi, 2020).

There are many good things for universities to promote through social media; among others, through social media, the presence of universities will continue to increase both to inform their activities and improve relations with existing ones (DeAndrea et al., 2012). By promoting programs and academic progress on social media platforms, universities will easily find prospective students, currently active students, and maintain good relations with students alumni (Peruta et al., 2018). The selection of promotional strategies through various social media can promote prospective new students and get prospective lecturers and other staff because this search is free, fast where there are potential candidates to join the University. However, on social media, there are also many emerging professional communities in academic tasks and agendas that make universities more popular and reach all levels of consumers (Khan \& Jan, 2015).

Another reason university administrators choose marketing on social media is to develop a college marketing brand (Peruta \& Shields, 2017). On online data, the issue of the name of a university is also important because the more often brand universities are raised, the more people will know and remember the name of the university institution (Pedersen \& Gram, 2018). This way is the right solution to inject seeds into the minds of prospective staff employees and new students. The reason is that the more familiar the name of a particular university is, the others will be forgotten when they need the University they are going to enroll in (Scolere et al., 2018).

For students who have academic achievements, this is an investment target to get talented students, so there is no doubt that these students will choose the brains they already know, which they see on several social media platforms (Irfan et al., 2017; Widhiasthini, 2020). This strategy is very distinctive where if an identity displays a series of achievements and is supported by high-quality teaching staff, then it is smothered by the environment and geographical location of the University. All will become a trend and a logo that is ready to advance the college. So that one of the advantages of promoting investment through social media is to maintain the University's brand reputation, which will further convince the University (Kaplan \& Haenlein, 2016).

Business people realize that social media has become the choice of many industries, government, and higher education managers, so they no longer hesitate to market their products on social media (Rodriguez, 2011). Fellow businessmen, such as social media and other companies or organizations, benefit by working together (Erdoğmuş \& Cicek, 2012). This is very important for university promotion managers because the strategies adopted by social media have proven to be very effective. Where social media can help prospective Bayer (Bayer et al., 2020) in this way, prospective students do not have to visit the University's website directly or come to campus directly. According to Tsimonis \& Dimitriadis (2014), the strategy to impress a company's brand through social media is very effective. They said that about $60 \%$ of students now are students at various universities in the US and several other Commonwealth countries get information about their chosen campus candidate from several social media platforms (Bosch, 2009).

Apart from that, according to the observations of domestic writers, many prospective students have chosen the University they are currently studying, they get a series of information and campus promotions through social networks (Deliens et al., 2014). So that many universities in Indonesia successfully market their university products and advantages through social media networks. This is why the industry needs to market its products to broaden how social media serves every organization that uses social media (Laserna \& Miguel, 2018). So social media, as much as possible, help promote every request that wants to reach student brokers throughout the country and even the whole world (Scolere et al., 2018).

Furthermore, we also want to underline that this marketing study does not emphasize comparing the two marketing media application systems, but this study focuses on how universities rely on social media (Schwemmer \& Ziewiecki, 2018). How do social media carry out the strategy with its commitment to serving consumer orders, in this case, the marketing of university products? Likewise, this study aims to find an in-depth understanding of how universities and customers from social media have gained in-depth knowledge of how strategies rather than social media are in serving every college promotion order to prospective students (Schillinger \& Wilkins, 1997). Thus, this study seeks to answer 
this royal problem by presenting arguments and explanations supported by evidence from field studies, especially how the marketing performance of high organ products is with the main focus on optimizing social media work to fill games that have been a problem in choosing media. As a means of marketing and other academic promotions (Aichner \& Jacob, 2015).

Next, many field findings will become supporting data in the results presentation section. We believe that the success of significant changes in choosing social media as a means of information and dissemination of promotions cannot be separated from the capabilities possessed by social media. So, overall this study will describe how universities have both domestically and abroad to increase cooperation with the social media industry in increasing the competitiveness of promotions to the broadest market share (Zhong et al., 2013). Thus, this paper can repeat its purpose, which is to find and discuss the results of the investigation of the effectiveness of higher education marketing strategies using social media applications (Strang, 2015).

\section{Materials and Methods}

This section will describe the procedure for carrying out this business review study to identify high-order ways of marketing products and services using social media applications to reach prospective students and other recruits (Appel et al., 2020). This study fully uses data in the form of evidence from previous studies published in various business and educational journals and books that discuss marketing issues and several websites that provide free information (Malhotra \& Malhotra, 2012). The first thing we did was try to formulate the problem and then proceed with searching for data electronically after the data was collected; we analyzed it in depth to get an understanding of the importance of the existence of media for business people, including leaders at universities in moving marketing to reach the most comprehensive community their business. We cannot use the data without going through an in-depth analysis process under the phenomenological approach of exploring the broadest possible way to answer cross and current study problems (Ali et al., 2016).

Obtain the latest data, and this study focuses on searching for data published between 2010 and 2001 considering that the last five years, the development of social media applications has been very intense as well as more and more business people who are participating in services and taking advantage of existing services on social media (Wang et al., 2012). From data search to analysis and finally compiling a reporting design, this study chose a design in a descriptive qualitative form by following several examples of similar interesting studies, namely studies in the economic and business fields where the use of social media for business and other educational purposes.

\section{Results and Discussions}

University leaders must master the marketing strategy of the products and services they need to sell (Shattock, 2010). The marketing factor is an essential element in running a college business if it wants to be the best and develop in an era of intense competition by utilizing various online methods, primarily relying on promotion and marketing through social media technology (Khalid et al., 2018). This is in line with the competition for social media applications because many university leaders invest intelligently in social media-based marketing efforts. It is undeniable that access to the internet is increasingly widespread, so the managers of social media resources have a big way and are very active in serving various marketing and promotions. Successful candidates can become popular platforms among the younger generation, including universities, to survive in higher education globally (Poulova \& Klímová, 2018).

When viewed from the business prospects of social media in collaboration with universities, managers of social media-based marketing by helping to promote higher education marketing, in other words, can create excellent benefits besides increasing collaboration involving students in achieving and maintaining an international reputation (Tiago \& Verissimo, 2014). Next, we will describe several effective strategies resulting from a study from various sources where social media can do marketing to prospective consumers of prospective students who have collaborated with several social media (Rutter et al., 2016).

A university strategy often encountered during marketing campaigns is placing advertisements on various social media platforms. The University carries out various ideas and message themes that seek to communicate the concept of products and services in an integrated manner (Quesenberry, 2020). Usually, universities hold campaigns on social media with a strategy to market products simultaneously on various social media platforms, either through radio, newspapers, TV both online and offline, with a variety of content but for one product goal (Harder et al., 2017). Judging

Sintani, L., Fransisca, Y., Anjarini, A. D., \& Mulyapradana, A. (2022). Identification of the effectiveness of higher

education marketing strategies using social media. International Research Journal of Management, IT and Social Sciences, 9(1), 1-9. https://doi.org/10.21744/irjmis.v9n1.1994 
from the strategy used, this is a perfect strategy in the digital era, when more and more people have smartphones searching for the desired products and services in the market. Marketing activities in this way are a priority strategy for branding and marketing university products. With marketing through social media, prospective students will know that the campus has many potential programs (Thackeray et al., 2008).

Many marketing activities on social media say it is identical to the funds owed by the agency. The greater the funds owned by an educational institution, it will generally result in a very sharp level of marketing that can be done (Tuten, 2020). However, funds are not above everything because marketing on social media is very cheap. Limited funds can be overcome with more intelligent and, more precisely, social media innovations; one solution that can be done is to highlight the achievements of university products. Marketing strategy is closely related to the dissemination of information to be conveyed to prospective new students. There are several ways to deliver this information strategy, such as making campus brochures and using advertisements other than social media (Chu \& Kim, 2011).

The following strategy is the strategy of creating content by social media users. This method is beneficial in communication opportunities and directly reaching social media friendships involving active students and alumni (Moogan, 2011). If it looks at the activity of students on various social media, this is a perfect strategy where students who are still active can be involved so that they participate in their respective social media page hours (Bélanger et al., 2014). Especially with making \#for colleges at major ongoing events, such as campus orientation graduations and reunion meetings in various cities. Such a brand allows students to be directly involved in marketing and will be witnessed by the broader community with university messages in the form of achievements and advantages of each University, of course, all through social media (Peruta \& Shields, 2017).

The strategy of forming social media groups can help universities connect with a fast audience and prospective students. Universities may have groups on several social media platforms such as a dedicated Facebook network apart from university activities that are devoted to serving a smaller audience within the university community; such as groups for each faculty department, alumni, hobby club groups, sports, and cultural arts groups, groups for student guardians, and job seekers groups (Smiciklas, 2012).

Because with the group running, this will be a good vehicle for holding meetings for discussions, sharing experiences and activities, announcements, and sharing all critical information with fellow group community members across cities and even countries (Wen, 2017). The group should have something specific with an exciting group theme and encourage participants to share and contribute with various information and student achievements so that the wider community will see the activities and progress of the University. Each group member must be active in managing every event that is intellectual and hobby. Equally important is that each group has a goal: promotion and indirect marketing of university programs and ensuring that all group members offer unique and new things to market university products and services (Shek et al., 2017).

The following framework makes a custom stage since all phases of online media are expected for different purposes and advantages to advance various training programs (Zhong et al., 2013). For instance, a phase can associate understudies with graduate classes to gather hierarchical and amicable situations through electronic media like LinkedIn and Quora. Instagram and Snapchat can post photographs and accounts, while discussions can happen on a phase like Quora. The vocation administrations office at the college strives to work on its organization for understudies and graduation classes utilizing Pinterest (Scolere et al., 2018). Pinterest and Flipboard can be utilized to grow brand mindfulness. Meanwhile, Medium and WordPress can disperse blog content for school associations (Frauenstein \& Flowerday, 2016).

The following strategy is posting explicit substance to the crowd. The main strategic goal of this web-based media system is to deliver appropriate content to an audience who is a potential buyer (Sanderson, 2011). As such, directors of online media and colleges should consider obtaining isolated records for different parts of campus life. For example, universities can have news to share from various divisions of scientific research findings, sports parties, and information about graduation ceremonies for graduating classes (Hayes et al., 2019; Aslan, 2021; Suroso et al., 2021). Someone who needs to look at the more prominent college sports news may not be interested in what is happening in their department. With more than hundreds of fans, accounts on the University's football players' social media are an outstanding achievement to impact the reputation of the University in the eyes of prospective students. So, if the University keeps separate notes for each program or division in the University, the promotional content would be better explicitly made for that particular group following each feedback with the emotional ties of the account holder and prospective students (O’Hallarn et al., 2016).

Live broadcast programs on social media have become one of the strategies for promoting and marketing university productions by sharing and connecting (Hanna et al., 2011). Through this stage, online media is on the rise-so live broadcasting and drawing with live event followers can be an excellent method of getting the attention of the masses. 
Live streaming is a viable method for establishing a stable web-based media presence. It also allows the audience to gain the necessary educational foundation's experience (Kesavan et al., 2021). Universities can share what is happening on the ground, from significant events to more modest studios. The promoter can even hold a live Q\&A meeting for future students. In like manner, how to make a class blog for discussion. Composing blog sections furnishes understudies with another asset for cutting edge material to interface back-to-class social channels adequately. There are different available stages, like WordPress, SquareSpace, Wix, Blogger, or Medium, where colleges can make class sites (Kietzmann et al., 2011). Understudies can take their customer notes to make discussion posts or add remarks at class prompts. Course timetables and tasks, refreshes, and any resources can be shared on the blog as a space of concentration. Assign blog sections as papers (Richardson, 2010). Having understudies make articles or compose impermanent designs on their sites is another method for uniting the web media and learning. Sites as semester-or broadened tasks can additionally foster understudies' straightforward design of unequivocal readiness and thinking. Have understudies respond to demands after many weeks, making them loose and coordinated true to form. Do whatever it takes not to feel bound to English or composing classes; the utilization of online media in training can move in all subjects (Hobbs, 2011).

Designing class blogs and various conversations is one way to inform prospective students about what material students will get when they become students (Ivala \& Gachago, 2012). This is the initial stage of the University introducing work programs which can be accessed by the broader community so that they can get early information about the reputation and programs offered to students in the future if they later choose to continue their education at their college so this is one of the blocks. In classes, both students and alumni can also give important notes to prospective new students so that they will later gain understanding and also the opportunity to have dialogue or contribute to getting information as well as commenting on the programs they will find when they enter school there. Blogging on the phone beside it got the video come on subtitles.

Thus, prospective students and parents of the wider community can use various channels on social media to get what information they will need later when they become participants in the tall tree (Hurt et al., 2012). Things like this have been carried out at various well-known universities globally, where they run a series of stories that are informative to prospective students, and even this program can also be accessed at previous level schools before they go to college. This is one of the advantages of social media where they can access the world of parasites become a source of inspiration and information when they later look for the right campus path and according to their wishes (Blankenship, 2011).

Creating a university blog page to share stories on social media pages provides an opportunity for students to read and participate in stories where they not only read but also contribute to storytelling, so in this way is a strategy to link the University with its programs on social media pages. Easily (Ráthonyi, 2013). With this strategy, both more challenging students and prospective students will get the opportunity to communicate, and even university instructors can post discussion posts and add and practice each comment to participate like a class (Kaplan \& Haenlein, 2016). Posting blogs and sharing stories is a simple way where university experts can interact with many publics and get each other's profiles so that there is a perfect relationship between investment and society in general, especially those who exist and are actively playing on social media so that it will a good relationship is established by telling stories and contributing with discussion questions and mutual comments (Ivala \& Gachago, 2012).

Likewise, creating interest-based social media groups is one strategy for universities to attract prospective students to join the University in the future. This group consists of active students or alumni who can join to get information and get information from each other tells stories about developments on issues of hobbies and interests and student majors on campus (Musial \& Sastry, 2012). So, here various programs can be delivered through groups on social media which will help explain information and campus developments, and also prospective students can join and find out what activities they can activate later when they become students there (Bechmann \& Lomborg, 2013). Assuming that investment can attract sympathy, prospective students and their parents will get information about convenience on campus, academic services, and the history of university profiles with everything that makes students interested in becoming learning participants, and campuses can post with various models videos about extracurriculars that can be enjoyed. They are already actively studying while the University handles this site and follows the existing rules utilizing internet-based media, allowing all people to join and be more fun (Dhelim et al., 2020).

Sintani, L., Fransisca, Y., Anjarini, A. D., \& Mulyapradana, A. (2022). Identification of the effectiveness of higher education marketing strategies using social media. International Research Journal of Management, IT and Social Sciences, 9(1), 1-9. https://doi.org/10.21744/irjmis.v9n1.1994 


\section{Conclusion}

We repeat once again; this study explores how effective the use of social media is for marketing products and services owned by universities to attract interests and candidates from their way students by utilizing social media services and presence. By examining various evidence from our field findings, we believe that we have answered the research questions on a valid and reliable basis. Based on previous findings and we have under the phenomenological approach, we believe that the data has provided the right way for Indonesia to promote or the right strategy for givers to more complicated to promote their products and services to reach all levels of society, especially prospective students who will present later.

The findings that we can conclude here, among others, since the last ten years with the emergence of various social media platforms, have turned out to be a separate phenomenon where public attention is not left behind by political business leaders and education, especially high-flying leaders who hope that the benefits of social media services can become a strategy for how the University promotes product and service package programs to reach layers of readers and especially new students. As for the programs they can do, for example, creating groups on social media, they can also create blogs and discussion boards where university administrators can interact directly with the community how the general public can reach their programs. Besides that, many other programs can be installed on social media where campuses, for example by placing campus programs such as students who are still active and alumni can mingle with the broader community, exchange information, share information, often discuss issues of local academics and also served in the future when they become permanent students there.

So through a less formal approach to social media services, here is a good strategy for campuses to reach as many levels of society as buyers and students, thus for students who are far from campus, there is no need to come directly to the management and campus in real, but they can reach invest in various services and products through exposure and creation in groups and other easy-to-operate features. So that the campus no longer has to use a marketing strategy with conventional media that does not allow the public and audio to interact directly with each other in two directions. It is hoped that these findings will serve as a guide and meaningful input for future researchers to develop business marketing science and social media, which is increasingly developing today.

\section{Conflict of interest statement}

The authors declared that they have no competing interests.

\section{Statement of authorship}

The authors have a responsibility for the conception and design of the study. The authors have approved the final article.

\section{Acknowledgments}

As a result, the author expresses his most profound gratitude for the support provided both academically and financially. We believe that this study will not run optimally without the support and assistance mentioned above. Once again, the authors express our gratitude and hope that in the future, a better relationship will be established. 


\section{References}

Aichner, T., \& Jacob, F. (2015). Measuring the degree of corporate social media use. International Journal of market research, 57(2), 257-276.

Ali, Z., Shabbir, M. A., Rauf, M., \& Hussain, A. (2016). To assess the impact of social media marketing on consumer perception. International Journal of Academic Research in Accounting, Finance and Management Sciences, 6(3), 69-77.

Appel, G., Grewal, L., Hadi, R., \& Stephen, A. T. (2020). The future of social media in marketing. Journal of the Academy of Marketing Science, 48(1), 79-95.

Aslan, A. (2021). The Relevance of Inquiry-Based Learning in Basic Reading Skills Exercises for Improving Student Learning Outcomes in Madrasah Ibtidaiyah. At-Tajdid: Jurnal Pendidikan dan Pemikiran Islam, 5(01), 28-41.

Bayer, J. B., Triệu, P., \& Ellison, N. B. (2020). Social media elements, ecologies, and effects. Annual review of psychology, 71, 471-497.

Bechmann, A., \& Lomborg, S. (2013). Mapping actor roles in social media: Different perspectives on value creation in theories of user participation. New media \& society, 15(5), 765-781.

Bélanger, C. H., Bali, S., \& Longden, B. (2014). How Canadian universities use social media to brand themselves. Tertiary Education and Management, 20(1), 14-29.

Biczysko, D., \& Jabłońska, M. R. (2016). Social media marketing tools among Polish public higher education institutions. European Journal of Educational \& Social Sciences, 1(1), 66-86.

Blankenship, M. (2011). How social media can and should impact higher education. Education Digest, 76(7), 39-42.

Bosch, T. E. (2009). Using online social networking for teaching and learning: Facebook use at the University of Cape Town. Communicatio: South African Journal for Communication Theory and Research, 35(2), 185-200.

Chu, S. C., \& Kim, Y. (2011). Determinants of consumer engagement in electronic word-of-mouth (eWOM) in social networking sites. International journal of Advertising, 30(1), 47-75.

DeAndrea, D. C., Ellison, N. B., LaRose, R., Steinfield, C., \& Fiore, A. (2012). Serious social media: On the use of social media for improving students' adjustment to college. The Internet and higher education, 15(1), 15-23. https://doi.org/10.1016/j.iheduc.2011.05.009

Deliens, T., Clarys, P., De Bourdeaudhuij, I., \& Deforche, B. (2014). Determinants of eating behaviour in university students: a qualitative study using focus group discussions. BMC public health, 14(1), 1-12.

Dewi, N. P. R. C. (2020). Digital marketing strategy on travel tourism businesses in marketing 4.0 era. International Research Journal of Management, IT and Social Sciences, 7(3), 58-64. https://doi.org/10.21744/irjmis.v7n3.898

Dhelim, S., Aung, N., \& Ning, H. (2020). Mining user interest based on personality-aware hybrid filtering in social networks. Knowledge-Based Systems, 206, 106227. https://doi.org/10.1016/j.knosys.2020.106227

Erdoğmuş, İ. E., \& Cicek, M. (2012). The impact of social media marketing on brand loyalty. Procedia-Social and Behavioral Sciences, 58, 1353-1360. https://doi.org/10.1016/j.sbspro.2012.09.1119

Frauenstein, E. D., \& Flowerday, S. V. (2016). Social network phishing: Becoming habituated to clicks and ignorant to threats?. In 2016 Information Security for South Africa (ISSA) (pp. 98-105). IEEE.

Hanna, R., Rohm, A., \& Crittenden, V. L. (2011). We're all connected: The power of the social media ecosystem. Business horizons, 54(3), 265-273. https://doi.org/10.1016/j.bushor.2011.01.007

Harder, R. A., Sevenans, J., \& Van Aelst, P. (2017). Intermedia agenda setting in the social media age: How traditional players dominate the news agenda in election times. The International Journal of Press/Politics, 22(3), 275-293.

Hayes, M., Filo, K., Riot, C., \& Geurin, A. (2019). Athlete perceptions of social media benefits and challenges during major sport events. International Journal of Sport Communication, 12(4), 449-481.

Hobbs, R. (2011). Digital and media literacy: Connecting culture and classroom. Corwin Press.

Hurt, N. E., Moss, G. S., Bradley, C. L., Larson, L. R., Lovelace, M., Prevost, L. B., ... \& Camus, M. S. (2012). The" Facebook" Effect: College Students' Perceptions of Online Discussions in the Age of Social Networking. International Journal for the Scholarship of Teaching and Learning, 6(2), n2.

Irfan, A., Rasli, A., Sami, A., \& Liaquat, H. (2017). Role of social media in promoting education tourism. Advanced Science Letters, 23(9), 8728-8731.

Ivala, E., \& Gachago, D. (2012). Social media for enhancing student engagement: The use of Facebook and blogs at a University of Technology. South African Journal of Higher Education, 26(1), 152-167.

Kaplan, A. M., \& Haenlein, M. (2016). Higher education and the digital revolution: About MOOCs, SPOCs, social media, and the Cookie Monster. Business Horizons, 59(4), 441-450. https://doi.org/10.1016/j.bushor.2016.03.008

Sintani, L., Fransisca, Y., Anjarini, A. D., \& Mulyapradana, A. (2022). Identification of the effectiveness of higher education marketing strategies using social media. International Research Journal of Management, IT and Social Sciences, 9(1), 1-9. https://doi.org/10.21744/irjmis.v9n1.1994 
Kesavan, S., Saravana Kumar, E., Kumar, A., \& Vengatesan, K. (2021). An investigation on adaptive HTTP media streaming Quality-of-Experience (QoE) and agility using cloud media services. International Journal of Computers and Applications, 43(5), 431-444.

Khalid, J., Ram, B. R., Soliman, M., Ali, A. J., Khaleel, M., \& Islam, M. S. (2018). Promising digital university: a pivotal need for higher education transformation. International Journal of Management in Education, 12(3), 264275.

Khan, M. F., \& Jan, A. (2015). Social media and social media marketing: A Literature Review. IOSR Journal of Business and Management, 17(11), 12-15.

Kietzmann, J. H., Hermkens, K., McCarthy, I. P., \& Silvestre, B. S. (2011). Social media? Get serious! Understanding the functional building blocks of social media. Business horizons, 54(3), 241-251. https://doi.org/10.1016/j.bushor.2011.01.005

Laserna, M. S. S., \& Miguel, M. C. (2018). Social media as a teaching innovation tool for the promotion of interest and motivation in higher education. In 2018 International Symposium on Computers in Education (SIIE) (pp. 1-5). IEEE.

Malhotra, N. K., \& Malhotra, N. K. (2012). Basic marketing research: Integration of social media. Boston: Pearson.

Moogan, Y. J. (2011). Can a higher education institution's marketing strategy improve the student-institution match?. International journal of educational management.

Musial, K., \& Sastry, N. (2012). Social media: are they underpinned by social or interest-based interactions?. In Proceedings of the Fourth Annual Workshop on Simplifying Complex Networks for Practitioners (pp. 1-6).

O'Hallarn, B., Morehead, C. A., \& Pribesh, S. L. (2016). Gaining STEAM: A general athletic department social media strategy. Journal of Issues in Intercollegiate Athletics, 9.

Pedersen, H. D., \& Gram, M. (2018). 'The brainy ones are leaving': the subtlety of (un) cool places through the eyes of rural youth. Journal of youth studies, 21(5), 620-635.

Peruta, A., \& Shields, A. B. (2017). Social media in higher education: Understanding how colleges and universities use Facebook. Journal of Marketing for Higher Education, 27(1), 131-143.

Peruta, A., Helm, C., \& Benson, J. (2018). Engaging university alumni through social media: strategies for creating community. The Journal of Social Media in Society Spring, 7(1), 123-150.

Poulova, P., \& Klímová, B. (2018). Emerging Technologies, Social Computing and University Promotion. In International KES Conference on Smart Education and Smart E-Learning (pp. 194-203). Springer, Cham.

Putra, P., Mizani, H., Basir, A., Muflihin, A., \& Aslan, A. (2020). The Relevancy on Education Release Revolution 4.0 in Islamic Basic Education Perspective in Indonesia (An Analysis Study of Paulo Freire's Thought). Test Engineering \& Management, 83, 10256-10263.

Quesenberry, K. A. (2020). Social media strategy: Marketing, advertising, and public relations in the consumer revolution. Rowman \& Littlefield Publishers.

Ráthonyi, G. (2013). Influence of social media on tourism-especially among students of the University of Debrecen. Applied Studies in Agribusiness and Commerce, 7(1), 105-112.

Richardson, W. (2010). Blogs, wikis, podcasts, and other powerful web tools for classrooms. Corwin press.

Rodriguez, J. E. (2011). Social media use in higher education: Key areas to consider for educators.

Rutter, R., Roper, S., \& Lettice, F. (2016). Social media interaction, the university brand and recruitment performance. Journal of Business Research, 69(8), 3096-3104. https://doi.org/10.1016/j.jbusres.2016.01.025

Sanderson, K. (2011). Lignocellulose: a chewy problem. Nature, 474(7352), S12-S14.

Schillinger, W. F., \& Wilkins, D. E. (1997). Deep ripping fall-planted wheat after fallow to improve infiltration and reduce erosion. Journal of soil and water conservation, 52(3), 198-202.

Schwemmer, C., \& Ziewiecki, S. (2018). Social media sellout: The increasing role of product promotion on YouTube. Social Media+ Society, 4(3), 2056305118786720.

Scolere, L., Pruchniewska, U., \& Duffy, B. E. (2018). Constructing the platform-specific self-brand: The labor of social media promotion. Social Media+ Society, 4(3), 2056305118784768.

Shattock, M. (2010). EBOOK: Managing Successful Universities. McGraw-Hill Education (UK).

Shek, D. T., Yuen-Tsang, A. W., \& Ng, E. C. (2017). USR network: A platform to promote university social responsibility. In University social responsibility and quality of life (pp. 11-21). Springer, Singapore.

Smiciklas, M. (2012). The power of infographics: Using pictures to communicate and connect with your audiences. Que Publishing.

Strang, K. D. (2015). Developing a goal-driven research strategy. In The Palgrave Handbook of Research Design in Business and Management (pp. 31-45). Palgrave Macmillan, New York. 
Sudarmo, S., Arifin, A., Pattiasina, P. J., Wirawan, V., \& Aslan, A. (2021). The Future of Instruction Media in Indonesian Education: Systematic Review. AL-ISHLAH: Jurnal Pendidikan, 13(2), 1302-1311.

Suroso, A., Hendriarto, P., Mr, G. N. K., Pattiasina, P. J., \& Aslan, A. (2021). Challenges and opportunities towards Islamic cultured generation: socio-cultural analysis. Linguistics and Culture Review, 5(1), 180-194.

Thackeray, R., Neiger, B. L., Hanson, C. L., \& McKenzie, J. F. (2008). Enhancing promotional strategies within social marketing programs: use of Web 2.0 social media. Health promotion practice, 9(4), 338-343.

Tiago, M. T. P. M. B., \& Verissimo, J. M. C. (2014). Digital marketing and social media: Why bother?. Business horizons, 57(6), 703-708. https://doi.org/10.1016/j.bushor.2014.07.002

Tsimonis, G., \& Dimitriadis, S. (2014). Brand strategies in social media. Marketing Intelligence \& Planning.

Tulu, D. T. (2017). Should online social Medias (OSMs) be banned at work? The impact of social Medias on employee productivity in Ambo University, a case study. Research in International Business and Finance, 42, $1096-1102$. https://doi.org/10.1016/j.ribaf.2017.07.044

Tuten, T. L. (2020). Social media marketing. Sage.

Wang, X., Yu, C., \& Wei, Y. (2012). Social media peer communication and impacts on purchase intentions: A consumer socialization framework. Journal of interactive marketing, 26(4), 198-208. https://doi.org/10.1016/j.intmar.2011.11.004

Wen, M. H. (2017). Applying gamification and social network techniques to promote health activities. In 2017 International Conference on Applied System Innovation (ICASI) (pp. 531-534). IEEE.

Widhiasthini, N. W. (2020). Sharing economy on election campaign through social media. International Research Journal of Management, IT and Social Sciences, 7(6), 79-85. https://doi.org/10.21744/irjmis.v7n6.1012

Zhong, R. Y., Li, Z., Pang, L. Y., Pan, Y., Qu, T., \& Huang, G. Q. (2013). RFID-enabled real-time advanced planning and scheduling shell for production decision making. International Journal of Computer Integrated Manufacturing, 26(7), 649-662.

Sintani, L., Fransisca, Y., Anjarini, A. D., \& Mulyapradana, A. (2022). Identification of the effectiveness of higher education marketing strategies using social media. International Research Journal of Management, IT and Social Sciences, 9(1), 1-9. https://doi.org/10.21744/irjmis.v9n1.1994 